\title{
Sea level and paleotemperature records from a mid-Holocene reef on the North coast of Java, Indonesia
}

\author{
Karem Azmy · Evan Edinger · Joyce Lundberg · \\ Wilfredo Diegor
}

Received: 26 December 2007 / Accepted: 26 October 2008

(C) Springer-Verlag 2008

\begin{abstract}
Mid-Holocene age fossil-fringing reefs occur along the tectonically stable north coast of Java, Indonesia, presenting an opportunity for sea level and paleoclimate reconstruction. The fossil reef at Point Teluk Awur, near Jepara, Central Java, contains two directly superposed horizons of Porites lobata microatolls. Corals in the lower horizon, $80 \mathrm{~cm}$ above modern sea level, yielded Uranium series dates of $7090 \pm 90$ year BP, while corals in the upper horizon at $1.5 \mathrm{~m}$ grew at $6960 \pm 60$ year BP. These dates match the transgressive phase of regional sea-level curves, but suggest a mid-Holocene highstand somewhat older than that recorded on mid-Pacific islands. Paleotemperature was calibrated using $\mathrm{Sr} / \mathrm{Ca}$ and $\delta^{18} \mathrm{O}$ values of a modern P. lobata coral and the locally measured sea surface temperature (SST), yielding SST-Sr/Ca and SST$\delta^{18} \mathrm{O}$ calibration equations $\left[T_{\mathrm{Sr} / \mathrm{Ca}}=91.03-7.35(\mathrm{Sr} / \mathrm{Ca})\right.$ and $T_{\delta^{18} \mathrm{O}}=-3.77$ to $\left.-5.52\left(\delta^{18} \mathrm{O}\right)\right]$. The application of the local equations to $\mathrm{Sr} / \mathrm{Ca}$ and $\delta^{18} \mathrm{O}$ measurements on these
\end{abstract}

\footnotetext{
K. Azmy $(\bowtie) \cdot$ E. Edinger · W. Diegor Department of Earth Sciences, Memorial University of Newfoundland, St John's, NL A1B 3X5, Canada

e-mail: kazmy@mun.ca

E. Edinger

Department of Geography,

Memorial University of Newfoundland,

St John's, NL A1B 3X9, Canada

E. Edinger

Department of Biology,

Memorial University of Newfoundland,

St John's, NL A1B 3X9, Canada

J. Lundberg

Department of Geography and Environmental Studies,

Carleton University, Ottawa, ON K1S 5B6, Canada
}

corals yielded a range of temperatures of $28.8 \pm 1.7^{\circ} \mathrm{C}$, comparable to that of the modern Java Sea $\left(28.4 \pm 0.7^{\circ} \mathrm{C}\right)$. A paleo-salinometer $\left[\Delta \delta^{18} \mathrm{O}=\partial \delta^{18} \mathrm{O} / \partial T\left(T_{\delta^{18} \mathrm{O}}-T_{\mathrm{Sr} / \mathrm{Ca}}\right)\right]$, re-calculated using the local parameters, also suggests Java Sea mid-Holocene paleosalinity similar to modern values.

Keywords Java Sea $\cdot$ Holocene $\cdot$ Sea level . Porites lobata $\cdot \mathrm{U} / \mathrm{Th} \cdot$ Paleoclimate

\section{Introduction}

Timing of the mid-Holocene eustatic sea level highstand has been recorded from fossil coral reefs throughout the tropical Pacific, Indian, and Atlantic oceans (e.g., Pirazolli et al. 1988; Chapell and Polach 1991; Hantoro et al. 1994; Hantoro 1997; Toscano and MacIntyre 2003; Camoin et al. 2004; Collins et al. 2006). Regional variation in the age of the mid-Holocene highstand likely reflects far-field glacioisostatic effects from northern hemisphere glacier loading (Toscano and MacIntyre 2003), and near-field effects of hydroisostasy (Hanebuth et al. 2000; Horton et al. 2005). The Sunda Shelf region, Indonesia, and particularly the Java Sea, is poorly represented in Holocene sea level and paleoclimatic studies. Although the age of flooding of the Sunda Shelf has been well-documented (Hanebuth et al. 2000), studies on fossil reefs are lacking because the moist climate tends to cause recrystallization of corals and other aragonitic fossils, while the tectonic stability of the Java Sea limits exposures of in situ fossil corals to reefs that grew above modern sea level. Therefore, a well-preserved fossil reef such as that described in this contribution is invaluable.

Investigation of the relationship between sea surface temperature (SST) and modern tropical climatic conditions is a key factor for understanding the Holocene paleoclimate 
and also modeling and predicting climatic events in our present time. Climatic, and oceanographic, variations have a clear impact on the isotopic and elemental chemical composition of the aragonitic $\left(\mathrm{CaCO}_{3}\right)$ skeleton of corals, which usually retain a record of the seasonal and annual climatic variations such as SST and sea surface salinity (SSS), and major flooding and Hurricane events (e.g., Hantoro et al. 1995, 1997; Pfeiffer et al. 2006; Hetzinger et al. 2008). Coral skeletons may also record anthropogenic effects such as the inputs of green-house gases and land use changes (Corrège 2006 and more references therein).

The current study investigates the age, sea-level record, and chemical and stable isotopic signatures recorded in Holocene Porites lobata fringing coral reefs near Jepara, Central Java. Perhaps because of its quasiestuarine character (Wyrtki 1961; Edinger et al. 2002), the applications of general tropical $\mathrm{Sr} / \mathrm{Ca}-\mathrm{SST}$ and $\delta^{18} \mathrm{O}-\mathrm{SST}$ equations to the local modern corals provided off-scale ranges of SST compared with the actually measured water temperatures.

The main objectives of the study are to (1) document the age and stratigraphy of a Holocene fossil reef from the tectonically stable North coast of Java; and (2) calculate reliable local $\delta^{18} \mathrm{O}$ and $\mathrm{Sr} / \mathrm{Ca}$ thermometers, for the study area, that can be used in the reconstruction of local midHolocene paleoclimatic conditions of SST and SSS.

\section{Study area and coral habitat}

A Holocene reef is exposed in an eroding cliff line at Point Teluk Awur, immediately south of the town of Jepara, Central Java (Fig. 1). The raised reef consists of two horizons of flat-topped P. lobata microatolls, one immediately above the other (Fig. 2a). Similar corals have been found beneath rice paddies up to $200 \mathrm{~m}$ inland. The flattopped morphology indicates that the corals grew up to sea level, probably in a reef flat setting and were re-inundated at a later stage. Bioerosion is common and the absence of clear death and overgrowth surfaces suggest that these corals likely grew to a stable or steadily rising sea level. The lower coral horizon lies between the modern high-tide line and $80 \mathrm{~cm}$ above the modern high-tide line, i.e., within the present day splash zone, while the upper horizon extends up a further $50 \mathrm{~cm}$. Multilobate non-microatoll Porites also occur in the upper horizon in overlapping lobes. The corals are overlain by approximately $50 \mathrm{~cm}$ thick coquinas, which are composed mainly of cockles (Anadara) and other mollusk shell and coral debris. The cockle shells are commonly articulated and occur in clusters forming condensed horizons showing no evidence of significant abrasion or fragmentation (Lescinsky et al. 2002). Unlike the well-preserved corals of the upper horizon, many of those in the lower horizon are recrystallized.

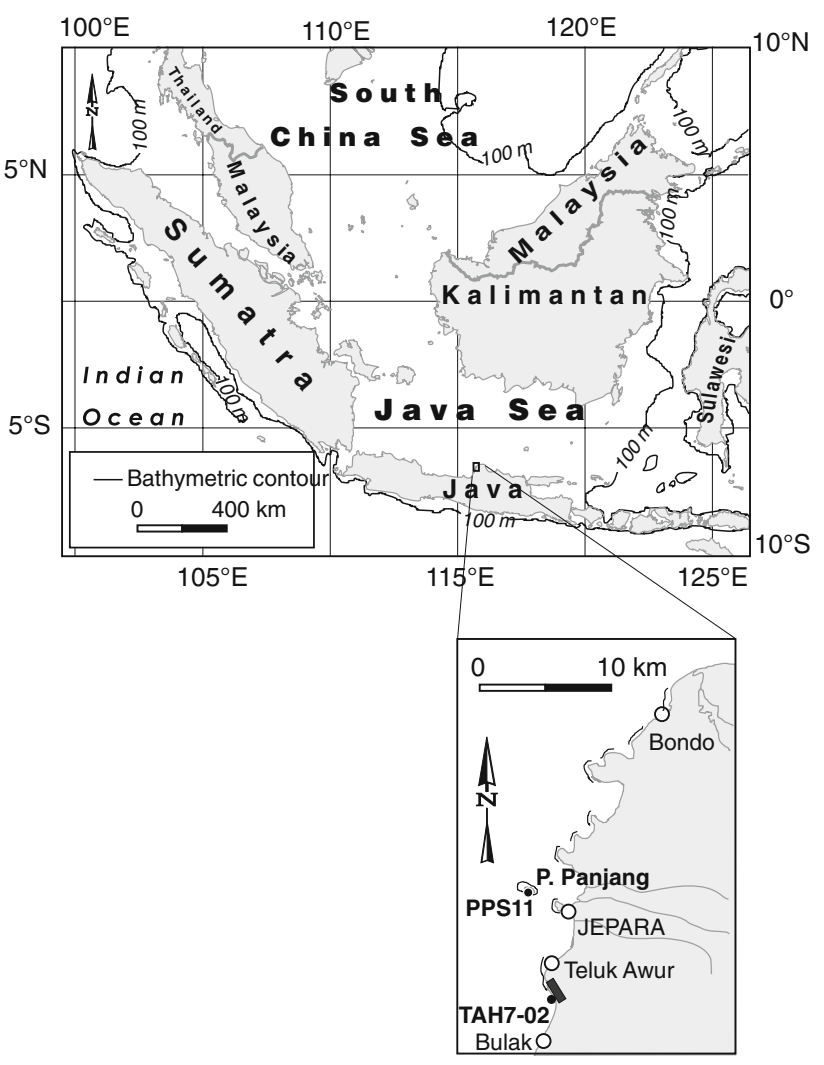

Fig. 1 Map of the Java Sea area showing the location of the studied corals

P. lobata fossil coral TAH2-7, from the upper horizon, was the best-preserved of the fossil corals collected, and was used in the geochemical studies.

A modern coral (PPS11) of P. lobata was sampled from Pulau Panjang, a sand cay $1 \mathrm{~km}$ west of Jepara, Central Java (Fig. 1) to be used as reference material for geochemical comparisons. The modern coral was collected at $1 \mathrm{~m}$ below mean tide from a fringing reef located on the southern (leeward) side of Pulau Panjang (Fig. 1), a coral cay approximately $2 \mathrm{~km}$ offshore from Jepara (Edinger et al. 2000a). The environmental conditions of the modern coral reef setting such as temperature, salinity, and light intensity, coral diversity, coral growth rates, internal bioerosion, and carbonate budgets, have been well documented (Edinger et al. 1998, 2000a; Holmes et al. 2000). The species composition of the fossil reef is statistically indistinguishable from that of the modern outer reef flat (Edinger et al. 2000b).

\section{Methods}

Radiometric age measurements

Blocks of skeleton weighing approximately $20 \mathrm{~g}$ each were cut from the fossil corals, pulverized, and ${ }^{14} \mathrm{C}$-dated using 
(a)

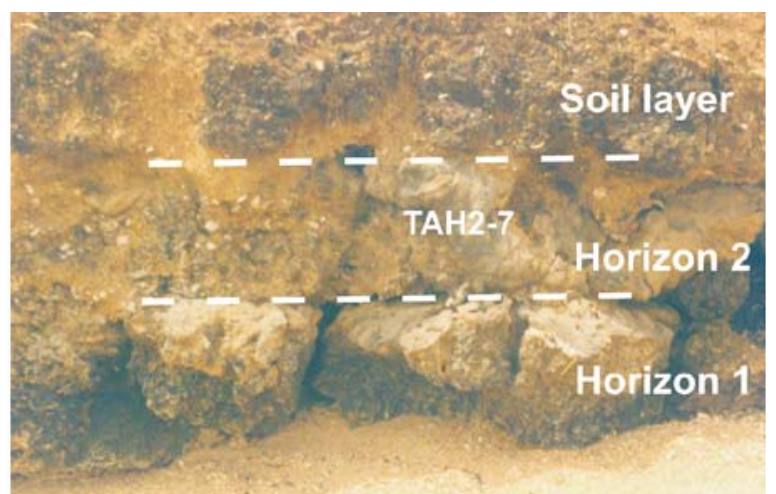

(b)
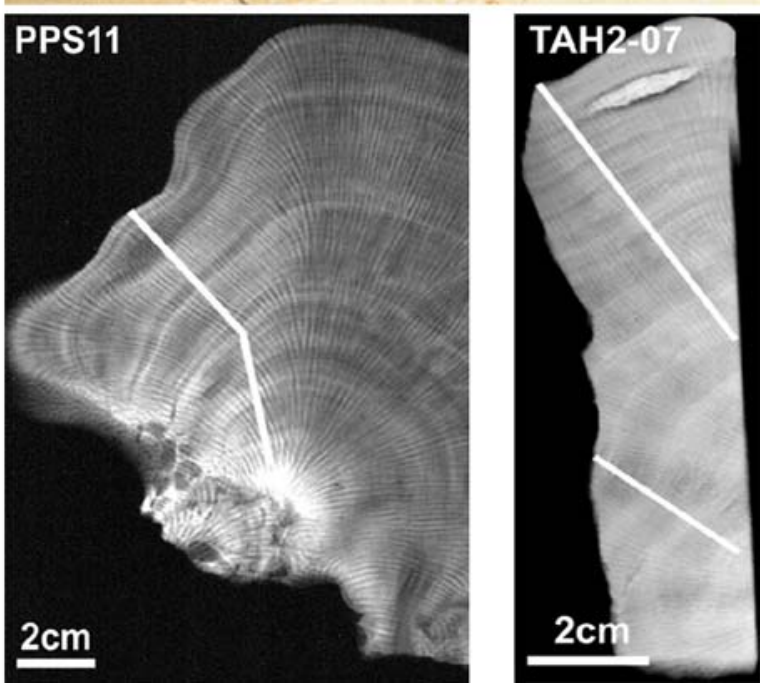

Fig. 2 Photos showing a the Holocene horizon of the investigated fossil coral TAH2-7 and b the X-ray images of the investigated modern and fossil corals (PPS11 and TAH2-7, respectively). The white lines in the X-ray images indicate the tracks of microsampling at an interval of $\sim 2 \mathrm{~mm}$

alpha counting at University of Waterloo, Ontario, Canada. Raw ${ }^{14} \mathrm{C}$ ages were corrected using the surficial water ${ }^{14} \mathrm{C}$ reservoir effect from Australia (+390 years; Mangerud 1972; Chapell and Polach 1991). Calibrated ages were determined using the Calib 5.0.1 program (Stuiver and Reimer 1993), against the IntCal04 ${ }^{14} \mathrm{C}$ radiocarbon calibration curve (Reimer et al. 2004).
The samples for U/Th dating were first checked for recrystallization using X-radiographs and X-ray diffraction (XRD) and only those of lowest calcite content selected (Table 2). About 1-3 g portions of the skeletons that showed no visible recrystallization were sampled for $\mathrm{U}$ and Th isotopic ratio measurement on the McMaster University VG 354 thermal ionization mass spectrometer (TIMS). Powdered samples were dissolved in $\mathrm{HNO}_{3}$ and spiked with a ${ }^{236} \mathrm{U}^{229} \mathrm{Th}$ spike. Uranium and thorium were co-precipitated with iron hydroxide, purified and separated on anion exchange columns (Dowex AG1-X 200-400 mesh). The thorium fraction was loaded onto zone-refined Re-Re double filament and the uranium fraction on Ta-Re double filament. Isotopic ratios were measured on the Daly multiplier in peak jumping mode. Uranium isotopic ratios were measured in two stages, and corrected for fractionation using the normal ${ }^{235} \mathrm{U} /{ }^{238} \mathrm{U}$ ratio. Thorium isotopic ratios were corrected only for mass discrimination on the multiplier. Because of detectable alteration in some samples, repeats were sampled from different parts of the specimen (Table 1).

Local and regional modern temperature and salinity data

Some of the recent seawater temperature measurements were recorded, for comparison purposes, using an Onset HOBO temperature logger deployed at $5 \mathrm{~m}$ depth at the modern reef sampling site (Edinger et al. 2000a). The temperature recorder was located subtidally, rather than intertidally, to reduce the risk of theft or tampering. Temperature was recorded ten times per $24 \mathrm{~h}$ day from July to early December, 1995. However, the monthly average SST for the 1-degree grid centered around $6.5^{\circ} \mathrm{S}$, $112.5^{\circ} \mathrm{E}$, was extracted from database of the CISL Research Data Archive (http://dss.ucar.edu), for the entire period January 1991 to December 1995, which covered the life-time span of the investigated recent coral PPS11. Similar procedure was followed to handle salinity measurements. Modern SSS was measured monthly between July and Dec 1995 using a hand-held refractometer, and monthly average SSS was extracted from the World Ocean

Table 1 U/Th ages correlated with calcite contents, measured by XRD, and ${ }^{14} \mathrm{C}$ data

\begin{tabular}{llllllll}
\hline Sample & Horizon & Calcite $\%$ & ${ }^{234} \mathrm{U} /{ }^{238} \mathrm{U}$ initial & ${ }^{234} \mathrm{U} /{ }^{238} \mathrm{U} \pm 2 \sigma \sigma$ & ${ }^{30} \mathrm{Th} /{ }^{234} \mathrm{U} \pm 2 \sigma$ & Age (U/Th) $\pm 2 \sigma$ & $\mathrm{Comment}$ \\
\hline TAH1-5 & 1 & 9 & 1.143 & $1.1404 \pm 0.0064$ & $0.0629 \pm 0.0008$ & $7,085 \pm 93$ & Good \\
TAH1-5r & 1 & 9 & 1.152 & $1.1490 \pm 0.0140$ & $0.0679 \pm 0.0005$ & $7,667 \pm 59$ & Altered \\
TAH1-6 & 1 & 3 & 1.110 & $1.1070 \pm 0.0130$ & $0.0699 \pm 0.0006$ & $7,904 \pm 71$ & Altered \\
TAH1-6r & 1 & 3 & 1.150 & $1.1474 \pm 0.0045$ & $0.0560 \pm 0.0007$ & $6,285 \pm 81$ & Altered \\
TAH2-1 & 2 & 3 & 1.157 & $1.1544 \pm 0.0054$ & $0.0614 \pm 0.0005$ & $6,910 \pm 58$ & Altered \\
TAH2-7 & 2 & 0 & 1.144 & $1.1415 \pm 0.0096$ & $0.0618 \pm 0.0005$ & $6,957 \pm 59$ & Good \\
\hline
\end{tabular}

Repeats are marked by letter " $r$ ". Height is measured from sea level baseline. See Fig. 2 for horizons 
Table 2 Corrected ${ }^{14} \mathrm{C}$ ages for samples, from University of Waterloo; XRD data from McMaster University

\begin{tabular}{lllllll}
\hline Sample & Horizon & Height $(\mathrm{cm})$ & Calcite $(\%)$ & Corr. ${ }^{14} \mathrm{C}$ age & Calibrated age $(2 \sigma)$ & Comment \\
\hline TA H1-2 & 1 & 60 & 6 & $5,400( \pm 80)$ & $5989-6318$ BP & Altered \\
TA H1-5 & 1 & 80 & 9 & $5,720( \pm 80)$ & $6437-6570$ BP & Altered \\
TA H1-6 & 1 & 70 & 3 & $6,280( \pm 80)$ & $6994-7335$ BP & Acceptible \\
TA H2-1 & 2 & 90 & 3 & $6,120( \pm 80)$ & $6791-7177$ BP & Acceptible \\
TA H2-6 & 2 & 100 & 0 & $5,470( \pm 80)$ & $6170-6411$ BP & Possibly altered \\
TA H2-7 & 2 & 100 & 0 & $6,010( \pm 80)$ & $6663-7028$ BP & Acceptible \\
\hline
\end{tabular}

Height indicates height of individual sample; the horizon of each coral sampled (hence growth to $80 \mathrm{~cm}$ or $1.30 \mathrm{~m}$ ) is indicated in the sample number. See Fig. 2 for horizons

Database (http://dss.ucar.edu) for the 1-degree grid around $6.5^{\circ} \mathrm{S}, 112.5^{\circ} \mathrm{E}$. The local and regional temperature and salinity data were comparable.

Elemental and stable isotope measurements

A slab, $\sim 8 \mathrm{~mm}$ thick, of each coral specimen (modern coral PPS11 and fossil Holocene coral TAH2-7) was cut along the main growth axis and X-rayed to identify density variations. The slabs were washed with de-ionized water and dried overnight at $50^{\circ} \mathrm{C}$. About $320 \mu \mathrm{g}$ were microsampled, with a low-speed microdrill, from each growth band at $2 \mathrm{~mm}$ sampling intervals. For $\mathrm{C}$ - and O-isotope analyses, $\sim 300 \mu \mathrm{g}$ of powder sample was reacted in inert atmosphere with ultrapure concentrated (100\%) orthophosphoric acid at $72{ }^{\circ} \mathrm{C}$ in a Thermo-Finnigan Gasbench II and the produced $\mathrm{CO}_{2}$ was automatically delivered to the isotope ratio mass spectrometer in a stream of helium and measured for isotope ratios. The laboratory standards NBS$19\left(\delta^{18} \mathrm{O}=-2.20 \%\right.$ and $\delta^{13} \mathrm{C}=+1.95 \%$ VPDB $)$ and NBS-18 $\left(\delta^{18} \mathrm{O}=-3.00 \%\right.$ and $\delta^{13} \mathrm{C}=-5.00 \%$ VPDB $)$ were repeatedly measured during each analysis run and yielded a routine precision $(2 \sigma)$ better than $0.1 \%$.

Major and trace element concentrations were determined at Memorial University of Newfoundland (MUN) using laser ablation-inductively coupled plasma mass spectrometry (LA-ICP-MS). The analytical system is a HP4500plus ICP-MS instrument coupled to a NUWAVE UP $213 \mathrm{~nm}$ NdYAG laser. The same slab, used for the stable isotopes, was fitted into the laser sample cell. Ablations were performed in helium carrier gas, which was combined with argon just prior to the feed to the torch. Nebulizer flow rates were about $0.9 \mathrm{l} / \mathrm{min} \mathrm{He}$ and $0.75 \mathrm{l} /$ min Ar. Laser energy was approximately $0.54 \mathrm{~mJ}$ (about $10 \mathrm{~J} / \mathrm{cm}^{2}$ ) at a laser repetition rate of $10 \mathrm{~Hz}$, producing an 80- $\mu \mathrm{m}$ diameter spot on the sample. Time resolved intensity data were acquired by peak-jumping in pulse-counting mode with 1 point measured per peak.

The internal standard element was ${ }^{44} \mathrm{Ca}$ and the Quadrupole settling time was $1 \mathrm{~ms}$ and the integration time (dwell time) was $10 \mathrm{~ms}$ on all masses. The total sampling time for each analysis run was $0.3785 \mathrm{~s}$ with an acquisition window of about $100 \mathrm{~s}$. Approximately $30 \mathrm{~s}$ of gas background data (with the laser beam blocked) were collected prior to each 60-s ablation of standards and unknowns. An international glass standard NBS 610 was used as reference (calibration) material and analyzed in the first two and last two positions of each run. Also, MACS-1, a pressed pellet coral aragonite standard from USGS, was run as an unknown sample to monitor accuracy and precision during analyses.

Data were re-produced using MUN's in-house CONVERT and LAMTRACE spreadsheet programs (Longerich et al. 1996). Accuracy and precision are estimated to be better than $10 \%$ based on the routine results from repeated analyses of various reference materials measured on dayto-day basis over several years. Detailed results of the geochemical analyses are listed in the Table 4.

\section{Results}

Radiometric age estimates and sea level record

The U/Th radiogenic age estimates (Table 1) suggest that the lower horizon of Porites grew at $7085 \pm 93$ (i.e., 70827178) year BP. The two dated corals in the upper horizon grew at $6910 \pm 58$ and $6957 \pm 59$ (i.e., 6842-7016) year BP. The ${ }^{14} \mathrm{C}$ measurements provided a range of calibrated ages between 5989 and 7028 year BP. In view of the considerable variation between these ages and those from U/Th dating, we suspect possible alteration and/or contamination with modern seawater ${ }^{14} \mathrm{C}$. Material thus altered produces artificially young ${ }^{14} \mathrm{C}$ ages, so the oldest age from each horizon is taken as the most accurate. The lowermost horizon radiocarbon dates range from 6791 to 7335 year BP, and the upper horizon from 6663 to 7028 year BP.

The best results from both dating methods indicate that the fossil reef dates from the early-mid-Holocene, and the upper horizon is about 100-150 years younger than the lower horizon (mean age difference 128 years, range 
66-336 years). The mean age estimate difference (100150 years, based on the U/Th results) for the two coral microatoll horizons vertically separated by $50 \mathrm{~cm}$, implies a sea level rise rate of approximately $3.9 \mathrm{~mm} / \mathrm{year}$ (range 3.3-5.0).

Evaluation of fossil coral preservation

Several tests were done to estimate sample preservation. Petrographic examination of the fossil-coral sample and Xray images (Fig. 2b) indicated no occurrence of meteoric cementation or secondary calcite in the sampled area (e.g., McGregor and Gagan 2003). XRD analysis indicated no alteration in the sampled portions of coral TAH2-7 (Tables 1,2 ), and the ${ }^{234} \mathrm{U} /{ }^{238} \mathrm{U}$ activity ratio indicated good preservation in this sample. The U/Th results were evaluated using the initial ${ }^{234} \mathrm{U} /{ }^{238} \mathrm{U}$ activity ratio as an indication of potential alteration: values more than $1 \%$ away from the modern sea-water value of 1.144 are probably altered. By this test, only two of the dated samples were clearly unaltered: TAH1-5 from the lower horizon and TAH2-7 from the upper horizon. Thus, the U/Th data yielded only one acceptable date for each horizon.

The clearest indication of preservation quality for each LA analysis stems from $\mathrm{Mn}$ and $\mathrm{Sr}$ contents in the skeletons. The statistical and graphic analyses of the trace element data showed no clear patterns, except for $\mathrm{Fe}$ and $\mathrm{Cu}$ (Table 4) which may exhibit a complex non-systematic relationship with $\delta^{18} \mathrm{O}$ values, likely influenced by soil contamination or detrital sediment incorporation into skeletons (Fig. 3). Diagenetic alteration of marine carbonates is associated with dramatic enrichment in $\mathrm{Mn}$ and depletion of $\mathrm{Sr}$, which makes these elements sensitive monitors of diagenesis (Veizer 1983). The fossil $P$. lobata coral TAH2-7 has $\mathrm{Mn}$ $(5 \pm 3 \mathrm{ppm}$, but with only four outliers extending to $75 \mathrm{ppm})$ and $\mathrm{Sr}(7458 \pm 327 \mathrm{ppm})$ contents nearly identical to those of its modern (PPS11, $4 \pm 3$ and $7487 \pm 141$, respectively) $P$. lobata counterpart (Fig. 4). The minor $\mathrm{Mn}$ enrichment and lack of Sr depletion in those outliers indicate a high degree of preservation. Also, both elements ( $\mathrm{Sr}$ and $\mathrm{Mn}$ ) show no correlation in either corals, which again supports the significant preservation of the studied fossil samples (Fig. 4). The few high Mn measurements in the fossil coral are likely inherited from some clay inclusions in the coral skeleton rather than altered material since these particular samples do not exhibit significant systematic depletion in their O-isotope signatures (Table 4).

Fossil coral geochemical data

The geochemical results of the fossil Holocene TAH2-7 are listed in the Table 4. Their Sr contents $(7,442 \pm 314$, $n=45$ ) were very slightly different from those of their
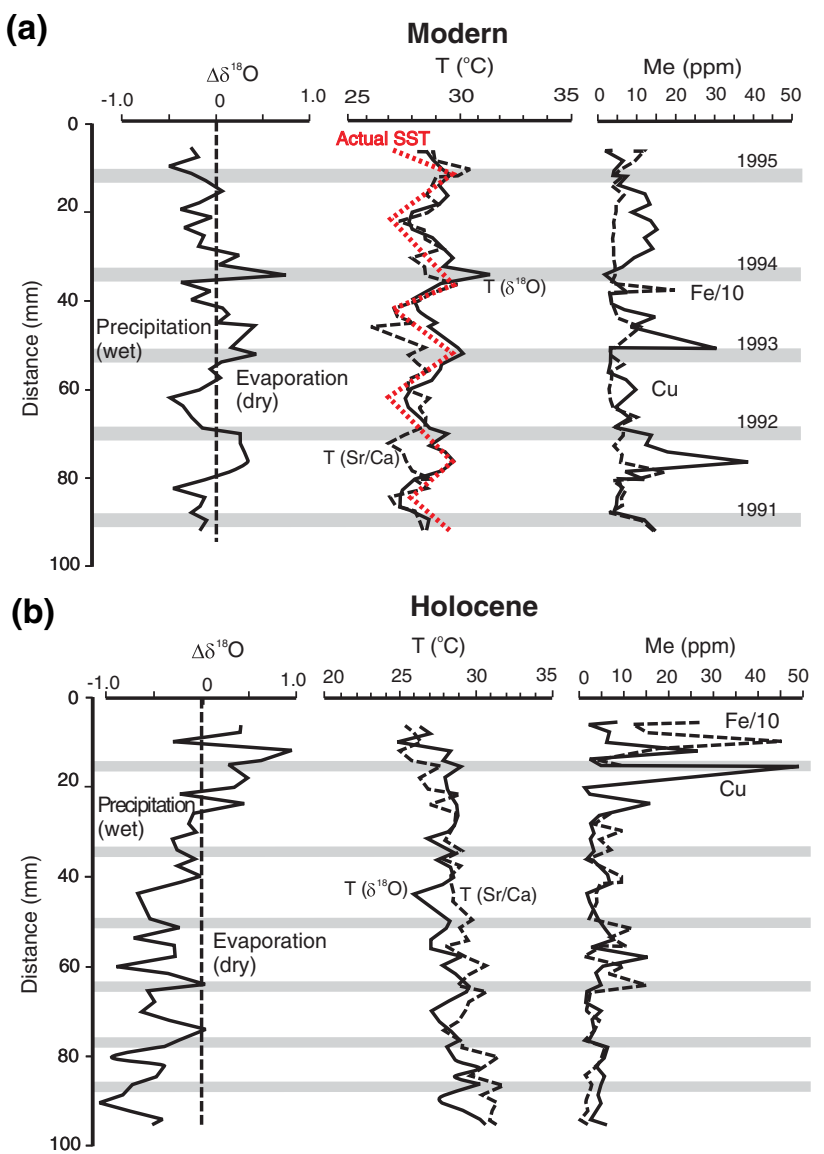

Fig. 3 Summary of (1) the $\mathrm{Fe}$ and $\mathrm{Cu}$ concentrations, (2) the $\mathrm{Sr} / \mathrm{Ca}-$ and $\delta^{18} \mathrm{O}-\mathrm{SST}$ patterns $\left[T_{\mathrm{Sr} / \mathrm{Ca}}=91.03-7.35(\mathrm{Sr} / \mathrm{Ca})\right.$ with a slope $=$ $-0.14, T_{\delta^{18} \mathrm{O}}=-3.77$ to $-5.52\left(\delta^{18} \mathrm{O}\right)$, with a slope $\left.=-0.18\right]$, and (3) the calculated salinity variations $\left[\Delta \delta^{18} \mathrm{O}=\partial \delta^{18} \mathrm{O} / \partial T\right.$ $\left(T_{\delta^{18} \mathrm{O}}-T_{\mathrm{Sr} / \mathrm{Ca}}\right)$, where $\left.\partial \delta^{18} \mathrm{O} / \partial T=0.18\right]$ across a core sample of $\mathbf{a}$ the modern (coral PPS11) and b fossil (coral TAH2-07) Porites lobata from the Java Sea (see text for details). Highlighted vertical grey bars mark the annual growth cycles. The microsampling interval is $\sim 2 \mathrm{~mm}$

modern counterpart $(7,489 \pm 145, n=44)$ and similarly their $\mathrm{Sr} / \mathrm{Ca}$ ratios varied from 7.8 to $9.3(\mathrm{mmol} / \mathrm{mol})$ with a mean value of $8.4 \pm 0.4$, which is very comparable to that of their modern counterpart $(8.5 \pm 0.2 \mathrm{mmol} / \mathrm{mol})$. The $\delta^{18} \mathrm{O}$ values of TAH2-7 vary from -6.6 to $-4.8 \%$ VPDB $(-5.8 \pm 0.3 \%, n=45)$ and are also very close to their modern counterpart $(5.8 \pm 0.2 \%)$.

Calibration of modern geochemical data to SST and SSS

The SST record of the Java Sea (CISL Research Data Archive, http://dss.ucar.edu/) during the life span (19911995) of the investigated modern coral (PPS11) of the current study indicates that annual temperature varied between $27 \pm 0.1$ and $29.7 \pm 0.1^{\circ} \mathrm{C}$. The $\mathrm{Sr} / \mathrm{Ca}$ ratios of the modern coral (Table 3) vary between 8.11 and 8.77 


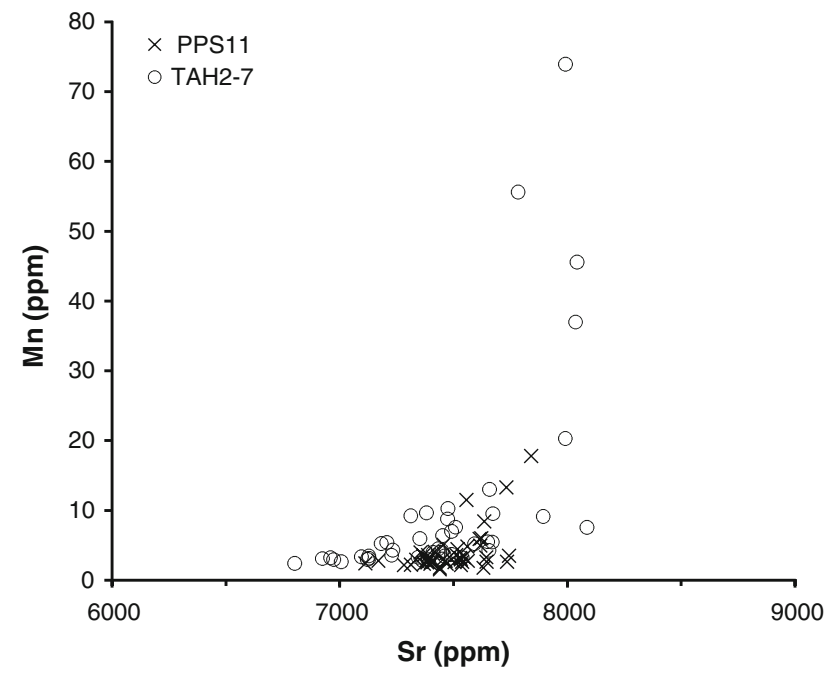

Fig. 4 A scatter diagram of $\mathrm{Sr}$ versus $\mathrm{Mn}$ in the investigated fossil (TAH2-7) and modern (PPS11) corals

Table 3 Statistical data of maximum and minimum values of measured annual SST in the study area and their correlated $\delta^{18} \mathrm{O}(\%$ VPDB) and $\mathrm{Sr} / \mathrm{Ca}(\mathrm{mol} / \mathrm{mmol})$ measurements of the investigated modern Porites lobata in Java Sea

\begin{tabular}{lllll}
\hline Year & & Annual $T\left({ }^{\circ} \mathrm{C}\right)$ & $\mathrm{Sr} / \mathrm{Ca}(\mathrm{mmol} / \mathrm{mol})$ & $\delta^{18} \mathrm{O}(\% \mathrm{VPDB})$ \\
\hline 1991 & Min. & 27.1 & 8.56 & -5.8 \\
& Max. & 29.7 & 8.11 & -6.1 \\
1992 & Min. & 27.0 & 8.69 & -5.6 \\
& Max. & 29.6 & 8.22 & -6.0 \\
1993 & Min & 27.1 & 8.73 & -5.7 \\
& Max & 29.7 & 8.44 & -6.3 \\
1994 & Min & 26.9 & 8.77 & -5.5 \\
& Max & 29.8 & 8.43 & -6.2 \\
1995 & Min. & 27.9 & 8.75 & -5.4 \\
& Max. & 29.6 & 8.49 & -5.8 \\
\hline
\end{tabular}

Annual SST $\left({ }^{\circ} \mathrm{C}\right)$ data of the study area, at Latitude $8^{\circ} \mathrm{S}$, extracted from the CISL Research Data Archive (see text for details)

$(\mathrm{mmol} / \mathrm{mol})$. Based on the present-day record of measured SST $\left({ }^{\circ} \mathrm{C}\right)$ and the $\mathrm{Sr} / \mathrm{Ca}(\mathrm{mmol} / \mathrm{mol})$ ratios of the investigated $P$. lobata (PPS11), a linear regression relationship $\left[T_{\mathrm{Sr} / \mathrm{Ca}}=91.03-7.35(\mathrm{Sr} / \mathrm{Ca}), \quad \mathrm{Sr} / \mathrm{Ca}\right.$ in $\left.\mathrm{mmol} / \mathrm{mol}\right]$ was calculated (Table 3 and Fig. 5a) for the Java Sea basin.

The $\delta^{18} \mathrm{O}$ values $(-5.9 \pm 0.3 \%, n=44)$ of the modern coral (PPS11) range from -6.3 to $-5.4 \%$ VPDB (Table 4). A local $\delta^{18} \mathrm{O}-\mathrm{SST}$ relationship $\left[T_{\delta^{18} \mathrm{O}}=-3.77\right.$ to $5.52\left(\delta^{18} \mathrm{O}\right), \delta^{18} \mathrm{O}$ in \%o VPDB] is calculated for the modern coral PPS11 (Table 3 and Fig. 5b) using the same recent water temperature record (CISL Research Data Archive, http://dss.ucar.edu/) applied for the calculated local $\mathrm{Sr} / \mathrm{Ca}$ thermometer.

The SSS varies in the study area between $~ 33$ to $35 \%$ during dry seasons and $\sim 28$ to $32 \%$ during rainy seasons
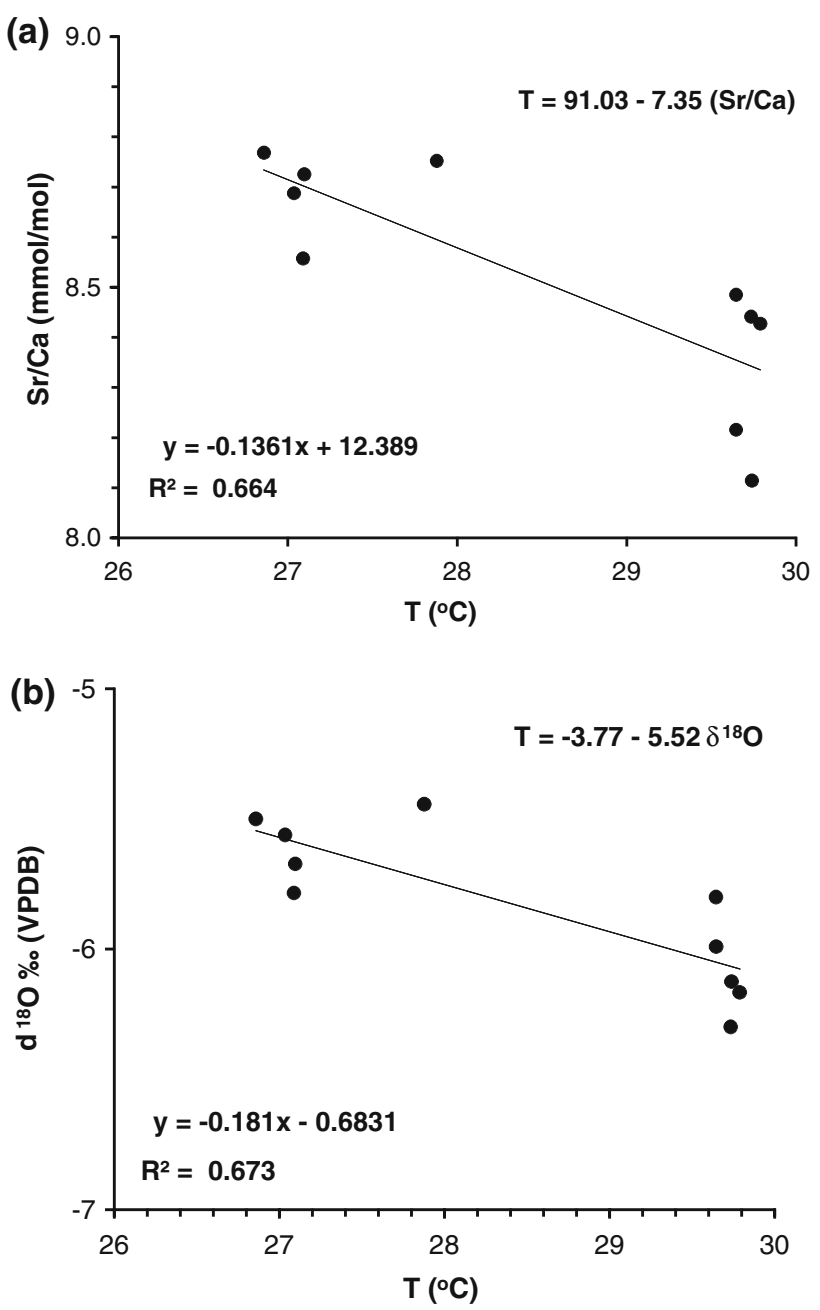

Fig. 5 Linear regressions of the measured annual SST versus a $\mathrm{Sr} / \mathrm{Ca}$ (mol/mmol) and $\mathbf{b} \delta^{18} \mathrm{O}$ (\%o VPDB) values of the investigated modern Porites lobata, which were used in the derivation of the local thermometers for the Java Sea. Data in Table 3

(Wyrtki 1961; Edinger et al. 2000a). The $\delta^{18} \mathrm{O}$ values (sensitive to salinity) of the modern coral (PPS11) are coupled with $\mathrm{Sr} / \mathrm{Ca}$ measurements (less sensitive to salinity) to reconstruct a paleo-salinometer by subtracting the temperature component from the coral $\delta^{18} \mathrm{O}$ to calculate the $\Delta \delta^{18} \mathrm{O}$ values $\left[\Delta \delta^{18} \mathrm{O}=\partial \delta^{18} \mathrm{O} / \partial \mathrm{T}\left(T_{\delta^{18} \mathrm{O}}-T_{\mathrm{Sr} / \mathrm{Ca}}\right)\right]$ corresponding to salinity changes (e.g., Gagan et al. 1998 and more references therein), where $\partial \delta^{18} \mathrm{O} / \partial T=0.18$ for the investigated (PPS11) P. lobata.

\section{Discussion}

Sea level record

Fossil coral microatolls at the Teluk Awur site appear to have grown in a very nearshore environment, probably the outer reef flat of a fringing reef (Edinger et al. 2000b). The 
abundance of carbonate sediments accumulating in narrow channels between coral heads suggests possible growth on a narrow reef flat. The presence of well-developed soils, and lack of marine deposits, above the second horizon of coral microatolls suggest that sea level did not much exceed the second coral horizon. The Teluk Awur raised corals suggest early-mid-Holocene sea levels of approximately $0.5-1.5 \mathrm{~m}$ above modern datum approximately 7000 year BP, which is generally consistent with published sea level curves for the Sunda Shelf (Hantoro 1997; Hanebuth et al. 2000) and peninsular Malaysia (Tjia 1996; Horton et al. 2005), but somewhat older than other western Pacific, Asian or Australian Holocene highstand estimates between 4000 and 6000 year BP age derived from coral reef records (Pirazolli et al. 1988; Woodroffe et al. 1995; Collins et al. 2006; Morimoto et al. 2007). Despite the post-Pliocene tectonic stability of the Sunda Shelf (Tjia 1980), the age of mid-Holocene relative sea level highstand is likely to be somewhat diachronous around the continental Southeast Asia region due to variation in hydroisostatic effects (Horton et al. 2005).

Relative sea level rose approximately $50 \mathrm{~cm}$ during the $100-150$ years separating the lower and upper horizons, suggesting a rate of sea-level rise of approximately 3$5 \mathrm{~mm} /$ year or roughly one third to one half of average sea level estimates of the Holocene transgression (McIntyre 1988; Fletcher 1992), but approximately matching midHolocene sea-level rise rates from the Malay-Thai peninsula (Horton et al. 2005). Because both horizons of corals are microatolls, the corals necessarily grew at sea level, eliminating sea level error associated with the depth range of the coral species (Scoffin and Stoddart 1978). Nonetheless, ecological time-averaging may have affected the temporal dimension of the sea level record (Edinger et al. 2007).

\section{$\mathrm{Sr} / \mathrm{Ca}$ Thermometer}

Reliable estimates of the past SST are critical in the reconstruction of reliable paleoclimatic models, which may provide better understanding of the present-day tropical climatic patterns and predict possible major events. Despite the relative variations in the effect of climate on the chemical composition of coral skeletons, the $\mathrm{Sr} / \mathrm{Ca}$ molar ratios and $\delta^{18} \mathrm{O}$ values of coral aragonite have proven to correlate strongly with the variations in SST (e.g., Weber and Woodhead 1972; Emiliani et al. 1978; Swart 1981; Schneider and Smith 1982; Lea et al. 1989; Beck et al. 1992; Gagan et al. 1998, 2004).

Attempts to apply previously published global tropical SST calibration equations to the $\mathrm{Sr} / \mathrm{Ca}$ values of Java Sea modern coral of the current study (PPS11) yielded ranges of temperature that were either far too low (Beck et al.
1992; de Villiers et al. 1994) or too high (Gagan et al. 1998) compared with the actual measured temperature of the ambient seawater in the study area. Gagan et al. (2000) investigated the $\mathrm{Sr} / \mathrm{Ca}-\mathrm{SST}$ relationships of many openwater tropical locals and calculated a representative general global equation $\left[T_{\mathrm{Sr} / \mathrm{Ca}}=168.2-15.674(\mathrm{Sr} / \mathrm{Ca})\right]$ for the entire tropical zone. However, the application of their thermometer to the $\mathrm{Sr} / \mathrm{Ca}$ ratios of the modern coral PPS11 of the current study from Java Sea still yielded an implausible range of temperatures $\left(28-41^{\circ} \mathrm{C}\right)$, which is up to $10^{\circ} \mathrm{C}$ higher than the present-day actual record $(\sim 27$ to $30^{\circ} \mathrm{C}$ ) of measured SST.

The discrepancy in the calculated $\mathrm{Sr} / \mathrm{Ca}$-based temperatures is possibly attributed to a combination of several factors, other than temperature, which may still contribute to the $\mathrm{Sr} / \mathrm{Ca}$ variations in corals (cf. Corrège 2006, more discussion therein). These could include extrinsic factors (environmental) such as the slight variability in the $\mathrm{Sr} / \mathrm{Ca}$ in seawater through space (de Villiers et al. 1994; de Villiers 1999) and time (Stoll and Schrag 1998), circulation patterns and salinity particularly in shallow seas such as the Java Sea (Edinger et al. 2002), and Ca concentration in seawaters (Ferrier-Pagès et al. 2002), and intrinsic factors (mainly biological) such as growth rate (McConnaughey 1989; Allison and Finch 2004; Cohen and Hart 2004), and the vital effect (e.g., the skeletogenesis biochemical mechanisms) on the incorporation of $\mathrm{Sr}^{+2}$ in the coralline aragonite and the secretion rate of $\mathrm{Ca}$ (cf. Corrège 2006, more discussion therein). It seems from the documented studies that the weight of effect contributed by each individual factor is hard to quantify and might be in itself insignificant unless combined with the rest of other effects.

The mechanism of $\mathrm{Sr}^{+2}$ incorporation into the coralline aragonite has been a controversial issue (e.g., Ip and Lim 1991; Reynaud et al. 2004) but most recent studies suggest that vital effects may influence the $\mathrm{Sr}^{+2}$ incorporation likely during daytime (e.g., Cohen et al. 2001; FerrierPagès et al. 2002; Al-Horani et al. 2003; Cohen and McConnaughey 2003; Reynaud et al. 2004). The $\mathrm{Sr} / \mathrm{Ca}$ ratios of $P$. lutea from southeastern Java (Indian Ocean coast) range from $\sim 8.7$ to 9.5 (Gagan et al. 1998) and they are slightly higher than those of the Java Sea $P$. lobata (8.11-8.77) of the current study. The greater range of $\mathrm{Sr} / \mathrm{Ca}$ values in corals from the Indian Ocean coast of Java may reflect greater seasonal amplitude of temperature variations than that observed in the Java Sea. Alternatively, the $\mathrm{Sr} / \mathrm{Ca}$ pattern might suggest that the vital effects vary among different species of Porites corals and have possibly a considerable influence on the $\mathrm{Sr} / \mathrm{Ca}$ ratios in corals (e.g., Suzuki et al. 2005). The variability in seawater chemistry and un-quantified vital effects on the $\mathrm{Sr} / \mathrm{Ca}$ ratios in corals are likely contributing factors that could explain the wide range of localized calibration $\mathrm{Sr} / \mathrm{Ca}-\mathrm{SST}$ equations 
developed from different tropical localities (e.g., Gagan et al. 2000). Although some earlier studies (e.g., Suzuki et al. 2005) documented some vital control on the O-isotopic composition of corals from the same species, the same effect on the $\mathrm{Sr} / \mathrm{Ca}$ ratio is still a matter of debate. The current investigation of the same species ( $P$. lobata) from modern and fossil samples of the same locality might inhibit the influence of the vital effect and may significantly reduce the effects of other related intrinsic factors.

The water chemistry of the Java Sea has received very little study, yet it has a unique nature. The broad shallow Java Sea exhibits quasi-estuarine characteristics of temperature, salinity, and wind mixing (Wyrtki 1961), and has been used as a modern analog for Paleozoic epeiric seas (Edinger et al. 2002) and carbonate-siliciclastic shelves (Azmy et al. 2006). It has relatively low salinity (33-35 psu in dry season vs. 28-32 psu in wet season), with precipitation generally exceeding evaporation, and receives input from several large rivers such as the Indonesian Borneo, Sumatra, and Java (Edinger and Browne 2000; Edinger et al. 2002). Despite the fact that $\mathrm{Sr}$ generally has a long residence time in the oceans, the quasi-estuarine nature of the Java Sea may reduce the overall concentration of $\mathrm{Sr}$ in the water relative to that in open ocean waters. The relatively lower concentrations of $\mathrm{Sr}$ in the Java Sea is most likely the main factor resulting in the higher range of calculated SST using the general equation of Gagan et al. (2000) that was based on $\mathrm{Sr} / \mathrm{Ca}$ in corals of open tropical ocean waters. Therefore, a local calibration equation of $\mathrm{Sr} / \mathrm{Ca}$ thermometer for the Java Sea was required for more reliable reconstruction of paleoclimate patterns in the area.

The measured molar $\mathrm{Sr} / \mathrm{Ca}$ ratios of the studied modern coral PPS11 (P. lobata) ranged from 8.11 to $8.77 \mathrm{mmol} /$ mol and were comparable with those of the fossil Holocene coral TAH2-7 (also P. lobata), which varied from 7.80 to $9.26 \mathrm{mmol} / \mathrm{mol}$ (Table 4). Assuming that the $\mathrm{Sr}^{+2}$ and $\mathrm{Ca}^{+2}$ concentrations in the Holocene Java seawater were similar to those of our present-day counterparts and that the skeletogenesis of coral aragonite was inorganic or involved comparable vital controls, since the investigated modern and fossil corals are of the same species (P. lobata), the $\mathrm{Sr} /$ $\mathrm{Ca}$ ranges suggest that the investigated modern and fossil Holocene corals lived in comparable SST conditions.

The only documented proxy SST for Holocene corals from Java area comes from the south coast of Java (Gagan et al. 2000), in the open water of the Indian Ocean $\left(8^{\circ} 31^{\prime} \mathrm{S}, 11^{\circ} 22^{\prime} \mathrm{E}\right)$ where conditions are different from those inside the Java Sea environment. In order to reconstruct a realistic paleoclimatic pattern for the fossil Holocene TAH2-7 coral, a localized calibration equation was calculated from the $\mathrm{Sr} / \mathrm{Ca}$ of the modern coral PPS11 and the present-day record of measured temperatures of the ambient Java seawater. The present-day record shows that the SST of the study area varied, during the investigated life span (1991-1995) of the modern coral PPS11, between $\sim 27$ and $30^{\circ} \mathrm{C}$ (CISL Research Data Archive, http://dss.ucar.edu/). A linear regression relationship (Table 3 and Fig. 5a) of the coral $\mathrm{Sr} / \mathrm{Ca}$ versus actual SST values $\left[T_{\mathrm{Sr} / \mathrm{Ca}}=91.03-7.35(\mathrm{Sr} / \mathrm{Ca}), \mathrm{Sr} / \mathrm{Ca}\right.$ in $\left.\mathrm{mmol} / \mathrm{mol}\right]$ provides a more reliable local calibration than the general tropical equation (Gagan et al. 2000) and consequently a more realistic SST pattern for the fossil coral TAH2-7. The local Java Sea calibration equation (Fig. 5a) has a slope comparable to that of the general calibrations suggested for the tropical zone (Gagan et al. 2000; Corrège 2006), but a much lower $y$-intercept.

The SST pattern of PPS11 (Fig. 3a) shows a 5-year record with an average value of $28.5 \pm 1.4^{\circ} \mathrm{C}$ and a steady long-term temperature rise over seasonal variations (26.9$29.8^{\circ} \mathrm{C}$ ) mainly around $28-29^{\circ} \mathrm{C}$. The temperature pattern of the fossil Holocene coral TAH2-7 (Fig. 3b), based on the $\mathrm{Sr} / \mathrm{Ca}$ thermometer calculated from the modern coral PSS11, exhibits approximately a 6-year record with an average value of $28.8 \pm 1.7^{\circ} \mathrm{C}$ and a pattern of seasonal variations within a range of $24.8-31.9^{\circ} \mathrm{C}$, which is very comparable with that of the modern coral although of slightly wider range (cf. Sun et al. 2005; Morimoto et al. 2007). On the other hand, the SST pattern of the fossil coral shows a slight cooling trend with decreasing time (Fig. 3b), suggesting that the coral might have survived, particularly during the late stages of its life span, under local temperature conditions possibly $\sim 2^{\circ} \mathrm{C}$ cooler than those of the modern counterpart. However, the interpretation of data has to be taken with caution since the estimated coral life span covers only 6 years. Although the inconsistent contents of $\mathrm{Fe}$ and $\mathrm{Cu}$ (Fig. 3b; Table 4) during that late life of the fossil coral might suggest possible incorporation of $\mathrm{Sr}$ from detrital inclusions due to riverine runoff of short-term floods, the parallel trend of temperature obtained from the $\delta^{18} \mathrm{O}$ profile (Fig. 3b) reflects no significant inputs of fresh water (see below). This may argue against any influence by a detrital source but rather possible contamination from the top soil layer (Fig. 2) and thus support a primary $\mathrm{Sr} / \mathrm{Ca}-$ SST profile for the fossil coral. This is also supported by the consistency in the ranges of SST of the modern and fossil corals $\left(28.5 \pm 1.4\right.$ and $28.8 \pm 1.7^{\circ} \mathrm{C}$, respectively) and their profiles (Fig. 3a, b).

\section{$\delta^{18} \mathrm{O}$ Thermometer}

The use of $\delta^{18} \mathrm{O}$ values of carbonates as a tracer of their ambient seawater has been established decades ago by the pioneer work of Epstein et al. (1953) and applied to carbonate skeletons of organisms that precipitate their shells in isotopic equilibrium with the seawater in which they 
live, such as brachiopods and foraminifers (cf. Veizer et al. 1999) as well as corals (e.g., Gagan et al. 2000; Corrège 2006). However, the vital effect of corals on the $\delta^{18} \mathrm{O}$ values of their skeletal aragonite is not fully understood and still a controversial issue (e.g., McConnaughey 1989; Cohen and McConnaughey 2003; Swart and Grottoli 2003; Allemand et al. 2004). The oxygen incorporated into the coralline aragonite has two different sources, the $\mathrm{CO}_{2}$ gas and the $\mathrm{CO}_{3}^{-2}$ anions in seawater, and the isotopic composition can be further considerably modified by respiration of the zooxanthellae during skeletogenesis (e.g., Rollion-Bard et al. 2003a,b). An earlier study by Suzuki et al. (2005) suggested a considerable vital effect on the $\delta^{18} \mathrm{O}$ composition (up to $\sim 1 \%$ ) of different Porites species from the same community. Intraspecies variability $(\sim 1 \%)$ was also documented particularly in the P. australiensis although the mean values of the counterpart variations $(\leq 0.23 \%)$ in the lobata (species investigated in the current study) were considerably lower (Suzuki et al. 2005, their Fig. 4). This may suggest that the contribution from the lobata vital effect to the calculated temperatures might be within about $1-2^{\circ} \mathrm{C}$.

In addition to vital effects, factors other than temperature might still contribute to the variations of $\delta^{18} \mathrm{O}$ values in the coralline aragonite (cf. Corrège 2006 for details). They include the long-term changes in the isotopic composition of seawater, freshening by meteoric water through precipitation and riverine inputs (decreased salinity), coral growth rate (extension rate), productivity, light levels, and $\mathrm{pH}$ values. These factors may have a considerable contribution to the variations in the calibration of a general tropical coral $\delta^{18} \mathrm{O}-\mathrm{SST}$ relationship. The global oxygenisotopic composition of seawater has not changed significantly since the Holocene, which excludes the influence of global seawater isotopic composition on the $\delta^{18} \mathrm{O}$ signal of the investigated corals of the current study. Also, both of the investigated corals, modern and Holocene) are of the same species ( $P$. lobata), which argues against a major influence by vital effects. Therefore, the most likely source of non-temperature related variations in $\delta^{18} \mathrm{O}$ values is the seasonal salinity fluctuation.

The considerable inter-species $\delta^{18} \mathrm{O}$ variations $(\sim 1 \%)$ in corals possibly caused by vital effects (e.g., Suzuki et al. 2005) might have contributed to the high temperature calculated from the general tropical equation by Gagan et al. (2000). In order to reconstruct a plausible SST scenario for the Holocene ocean water, a local $\delta^{18} \mathrm{O}-\mathrm{SST}$ relationship $\left[T_{\delta^{18} \mathrm{O}}=-3.77\right.$ to $-5.52\left(\delta^{18} \mathrm{O}\right), \delta^{18} \mathrm{O}$ in \%o VPDB] was established for the modern coral PPS11 (Table 3 and Fig. 5b) based on the same present day water temperature record (CISL Research Data Archive, http://dss.ucar.edu/) used for the reconstruction of the $\mathrm{Sr} /$ $\mathrm{Ca}$ thermometer.
The $\delta^{18} \mathrm{O}$ profiles of the fossil Holocene coral TAH2-7 had a range of seasonal temperatures (Fig. 3b) similar to that of the modern sample (Fig. 3a), since the average $\delta^{18} \mathrm{O}$ of the tropical Holocene seawater was similar to that of our present-day (Gagan et al. 1998, 2000 more references therein). The $\delta^{18} \mathrm{O}$ trend over time shown in the fossil coral record was also consistent with its $\mathrm{Sr} / \mathrm{Ca}-\mathrm{SST}$ profile (Fig. 3b). The slight offset between the $\delta^{18} \mathrm{O}-\mathrm{SST}$ and $\mathrm{Sr} /$ $\mathrm{Ca}-\mathrm{SST}$ curves in both of the investigated corals is most likely due to the fact that sampling for stable isotope measurements was carried out by a $0.6 \mathrm{~mm}$-microdrill bit whereas the $\mathrm{Sr} / \mathrm{Ca}$ analyses were run using a much narrower $(80 \mu \mathrm{m}$-wide) laser beam, and were thus more influenced by the relative heterogeneity in distribution of $\mathrm{Sr}$ in the skeletal coralline aragonite (cf. Edinger et al. 2008).

Implications for Surface Seawater Salinity (SSS)

The $\delta^{18} \mathrm{O}$ values of coralline aragonite are sensitive to the SSS variations which is a direct response to evaporation $\left(\delta^{18} \mathrm{O}\right.$ enrichment) during the dry seasons and dilution ( $\delta^{18} \mathrm{O}$ depletion) by meteoric water during the rainy seasons and high riverine runoff (cf. Corrège 2006). This is particularly relevant for corals growing within or close to zones of river inputs such as those of the current study (Fig. 1). Salinity variations in modern seawater in the nearshore locations of the study area range from 33 to $35 \%$ during dry seasons and 28 to $32 \%$ during rainy seasons (Wyrtki 1961), and from 32 to 34\%o annually further from shore (World Ocean Database). Coupling the $\delta^{18} \mathrm{O}$ with $\mathrm{Sr} /$ Ca measurements (less sensitive to salinity) of coralline aragonite may provide a potential relationship that can be used for the reconstruction of a reliable paleo-salinometer (e.g., McCulloch et al. 1994; Gagan et al. 1998, 2000; Hendy et al. 2002; see also Corrège 2006 for a review) by subtracting the temperature component from the coral $\delta^{18} \mathrm{O}$ to calculate the $\Delta \delta^{18} \mathrm{O}$ values $\left[\Delta \delta^{18} \mathrm{O}=\partial \delta^{18} \mathrm{O} / \partial T\right.$ $\left.\left(T_{\delta^{18} \mathrm{O}}-\mathrm{T}_{\mathrm{Sr} / \mathrm{Ca}}\right)\right]$ corresponding to salinity changes (e.g., Gagan et al. 2000), where $\partial \delta^{18} \mathrm{O} / \partial T=0.18$ for the investigated (PPS11) P. lobata. Since the boundary between dry and wet seasons can be defined at $\Delta \delta^{18} \mathrm{O}=0$ (e.g., Gagan et al. 2000), a $\Delta \delta^{18} \mathrm{O}$-time profile can be plotted and the relative position of the profile to the zero level of $\Delta \delta^{18} \mathrm{O}$ may indicate the prevailing dry versus wet conditions (Fig. 3b). On average, the paleosalinity recorded by the Holocene fossil coral was not dramatically different from modern salinity, implying that Java Sea mid-Holocene climate was also not radically different from our modern climate. This may suggest that the moist tropical Java Sea Basin had relatively different climate compared with the warmer and drier mid-Holocene paleoclimate records reconstructed from corals in subtropical or monsoonal 
regions of relatively higher latitudes such as the South China Sea (e.g., Sun et al. 2005), the southern coast of Java (Gagan et al. 1998, 2000), the Great Barrier Reef (Gagan et al. 2000), or western Australia (Gagan et al. 2000; Corrége et al. 2006, more references therein).

\section{Conclusions}

A mid-Holocene fossil reef consisting of two superposed horizons of microatolls grew under rising eustatic sea level conditions about 7000 year BP (mid-Holocene) on the tectonically stable north coast of Java. The two horizons, vertically separated by $50 \mathrm{~cm}$, grew approximately 150 years apart, suggesting an approximate rate of sea level rise of $3 \mathrm{~mm} / \mathrm{year}$, consistent with regional estimates of mid-Holocene sea level rise rate and timing.

Local Sr/Ca-SST and $\delta^{18} \mathrm{O}-\mathrm{SST}$ calibrations were calculated from a modern coral ( $P$. lobata) from the central Java coast (Quasi-estuarine conditions). The equations were applied to a mid Holocene fossil coral of the same species and from the same locality. The mid-Holocene tropical climatic conditions reconstructed from the fossil coral were not significantly different from present-day conditions in the area. However, the interpretations of the Java corals have to be taken with caution since the investigated part of the fossil spans a very short time interval (only $\sim 6$ years).
Paleoclimatic proxies recorded in coral skeletons from equatorial environments with restricted circulation and generally low salinity resulting from consistently high riverine influence, such as the Java Sea, were different from their tropical or sub-tropical open-ocean counterparts. Quasi-estuarine conditions likely reduced the Sr concentrations in water, which makes the application of general $\mathrm{Sr} / \mathrm{Ca}-\mathrm{SST}$ and $\delta^{18} \mathrm{O}-\mathrm{SST}$ relationships unreliable. Instead, local calibration equations have to be calculated for further reconstruction of Holocene paleoclimatic patterns in areas without open ocean conditions.

More extensive study of well-preserved fossil corals, although they are relatively rare in such a moist environment, is strongly recommended to better understand the Holocene paleoclimate of the Java Sea.

Acknowledgments We thank Drs Wolf-Christian Dullo, Jens Zinke and an anonymous reviewer for their constructive reviews of this manuscript. The manuscript also benefited from comments by $\mathrm{N}$. Catto, J. Rendell, and O. Sherwood. This project was funded by research grants from the Memorial University of Newfoundland (to Karem Azmy) and the Natural Sciences and Engineering Research Council of Canada (to Evan Edinger and Joyce Lundberg), and by a Geological Society of America student grant (to Evan Edinger).

Table 4 Samples, measurement positions, $\delta^{18} \mathrm{O}$ in \%o VPDB, and trace element contents of the studied cores from the Java Sea corals

\begin{tabular}{|c|c|c|c|c|c|c|c|c|}
\hline Sample id & Vertical distance $(\mathrm{mm})$ & $\mathrm{CaO}(\%)$ & $\mathrm{MgO}(\%)$ & $\mathrm{Sr}(\mathrm{ppm})$ & $\mathrm{Mn}(\mathrm{ppm})$ & $\mathrm{Fe}(\mathrm{ppm})$ & $\mathrm{Cu}(\mathrm{ppm})$ & $\overline{\delta^{18} \mathrm{O}(\% \mathrm{VPDB})}$ \\
\hline PPS-11-01 & 6.4 & 57.29 & 0.25 & 7,401 & 3 & 116 & 2 & -5.8 \\
\hline PPS-11-02 & 8.4 & 58.20 & 0.40 & 7,512 & 4 & 92 & 6 & -5.9 \\
\hline PPS-11-03 & 10.3 & 57.02 & 0.24 & 7,112 & 2 & 54 & 4 & -6.0 \\
\hline PPS-11-04 & 11.8 & 56.79 & 0.19 & 7,169 & 3 & 46 & 4 & -6.1 \\
\hline PPS-11-05 & 14.0 & 57.18 & 0.20 & 7,398 & 2 & 39 & 5 & -6.0 \\
\hline PPS-11-06 & 16.2 & 56.54 & 0.24 & 7,355 & 4 & 64 & 12 & -6.1 \\
\hline PPS-11-07 & 18.3 & 57.31 & 0.25 & 7,367 & 4 & 47 & 13 & -6.0 \\
\hline PPS-11-08 & 20.2 & 57.41 & 0.21 & 7,464 & 3 & 46 & 8 & -5.6 \\
\hline PPS-11-09 & 22.2 & 56.50 & 0.23 & 7,545 & 3 & 39 & 13 & -5.6 \\
\hline PPS-11-10 & 24.1 & 56.60 & 0.21 & 7,381 & 3 & 42 & 15 & -5.6 \\
\hline PPS-11-11 & 26.0 & 56.95 & 0.20 & 7,416 & 4 & 36 & 12 & -5.9 \\
\hline PPS-11-12 & 28.4 & 57.71 & 0.22 & 7,394 & 3 & 39 & 14 & -6.0 \\
\hline PPS-11-13 & 30.5 & 57.30 & 0.22 & 7,559 & 5 & 42 & 9 & -6.2 \\
\hline PPS-11-14 & 32.5 & 58.58 & 0.20 & 7,634 & 8 & 44 & 6 & -6.0 \\
\hline PPS-11-15 & 34.5 & 57.24 & 0.18 & 7,454 & 3 & 43 & 2 & -6.7 \\
\hline PPS-11-16 & 36.5 & 57.90 & 0.20 & 7,312 & 2 & 35 & 4 & -6.0 \\
\hline PPS-11-17 & 38.5 & 57.35 & 0.18 & 7,563 & 3 & 192 & 7 & -5.8 \\
\hline PPS-11-18 & 40.3 & 56.74 & 0.20 & 7,439 & 2 & 34 & 4 & -5.6 \\
\hline PPS-11-19 & 42.1 & 56.89 & 0.16 & 7,631 & 2 & 42 & 7 & -5.7 \\
\hline PPS-11-20 & 43.9 & 56.97 & 0.17 & 7,617 & 5 & 50 & 14 & -5.8 \\
\hline
\end{tabular}


Table 4 Appendix continued

\begin{tabular}{|c|c|c|c|c|c|c|c|c|}
\hline Sample id & Vertical distance $(\mathrm{mm})$ & $\mathrm{CaO}(\%)$ & $\mathrm{MgO}(\%)$ & $\mathrm{Sr}(\mathrm{ppm})$ & $\mathrm{Mn}(\mathrm{ppm})$ & $\mathrm{Fe}(\mathrm{ppm})$ & $\mathrm{Cu}(\mathrm{ppm})$ & $\delta^{18} \mathrm{O}(\% \mathrm{VPDB})$ \\
\hline PPS-11-21 & 45.3 & 55.74 & 0.19 & 7,335 & 3 & 72 & 9 & -5.9 \\
\hline PPS-11-22 & 46.2 & 56.49 & 0.17 & 7,735 & 3 & 107 & 8 & -5.8 \\
\hline PPS-11-23 & 50.9 & 56.90 & 0.18 & 7,410 & 3 & 43 & 30 & -6.2 \\
\hline PPS-11-24 & 52.4 & 56.25 & 0.15 & 7,439 & 2 & 34 & 4 & -6.3 \\
\hline PPS-11-25 & 54.5 & 57.43 & 0.16 & 7,532 & 2 & 62 & 3 & -6.0 \\
\hline PPS-11-26 & 56.1 & 56.04 & 0.17 & 7,282 & 2 & 33 & 3 & -6.0 \\
\hline PPS-11-27 & 58.0 & 56.97 & 0.17 & 7,538 & 3 & 33 & 7 & -5.9 \\
\hline PPS-11-28 & 60.5 & 55.80 & 0.14 & 7,384 & 3 & 31 & 9 & -5.6 \\
\hline PPS-11-29 & 62.3 & 56.80 & 0.17 & 7,370 & 2 & 34 & 7 & -5.5 \\
\hline PPS-11-30 & 64.3 & 57.04 & 0.16 & 7,469 & 2 & 35 & 5 & -5.5 \\
\hline PPS-11-31 & 66.7 & 57.27 & 0.17 & 7,455 & 5 & 96 & 8 & -5.7 \\
\hline PPS-11-32 & 68.9 & 57.83 & 0.17 & 7,531 & 3 & 40 & 4 & -5.8 \\
\hline PPS-11-33 & 70.7 & 56.64 & 0.15 & 7,517 & 4 & 62 & 13 & -6.1 \\
\hline PPS-11-34 & 72.8 & 57.36 & 0.18 & 7,731 & 13 & 42 & 12 & -5.8 \\
\hline PPS-11-35 & 74.7 & 57.22 & 0.22 & 7,614 & 6 & 63 & 17 & -6.1 \\
\hline PPS-11-36 & 76.8 & 58.35 & 0.17 & 7,743 & 4 & 56 & 37 & -6.2 \\
\hline PPS-11-37 & 78.8 & 57.99 & 0.19 & 7,643 & 3 & 169 & 7 & -6.0 \\
\hline PPS-11-38 & 80.9 & 57.05 & 0.17 & 7,504 & 3 & 38 & 5 & -5.6 \\
\hline PPS-11-39 & 82.9 & 56.82 & 0.19 & 7,387 & 4 & 70 & 6 & -5.5 \\
\hline PPS-11-40 & 84.8 & 56.65 & 0.21 & 7,621 & 6 & 59 & 5 & -5.4 \\
\hline PPS-11-41 & 86.8 & 57.09 & 0.16 & 7,645 & 3 & 60 & 5 & -5.4 \\
\hline PPS-11-42 & 88.1 & 57.25 & 0.18 & 7,529 & 3 & 29 & 4 & -5.6 \\
\hline PPS-11-43 & 90.1 & 57.71 & 0.21 & 7,556 & 12 & 108 & 12 & -5.8 \\
\hline PPS-11-44 & 92.3 & 60.11 & 0.23 & 7,841 & 18 & 138 & 14 & -5.8 \\
\hline TAH2-7-01 & 6.3 & 56.64 & 0.16 & 7,991 & 20 & 119 & 3 & -5.3 \\
\hline TAH2-7-02 & 7.8 & 57.64 & 0.17 & 8,036 & 37 & 152 & 7 & -5.4 \\
\hline TAH2-7-03 & 9.9 & 58.09 & 0.22 & 7,992 & 74 & 451 & 6 & -4.8 \\
\hline TAH2-7-04 & 11.9 & 56.82 & 0.15 & 8,086 & 8 & 181 & 27 & -5.8 \\
\hline TAH2-7-05 & 14.0 & 56.52 & 0.12 & 7,894 & 9 & 45 & 3 & -5.7 \\
\hline TAH2-7-06 & 15.4 & 57.50 & 0.14 & 7,670 & 5 & 94 & 5 & -5.9 \\
\hline TAH2-7-07 & 18.0 & 56.39 & 0.24 & 7,784 & 56 & & 22 & -5.7 \\
\hline TAH2-7-08 & 20.2 & 56.23 & 0.14 & 7,649 & 6 & 41 & 2 & -5.7 \\
\hline ТАH2-7-09 & 21.6 & 56.95 & 0.14 & 7,363 & 3 & 30 & 3 & -5.8 \\
\hline TAH2-7-10 & 23.8 & 59.33 & 0.20 & 8,043 & 46 & & 16 & -5.9 \\
\hline TAH2-7-11 & 25.8 & 58.92 & 0.17 & 7,672 & 10 & 67 & 5 & -5.9 \\
\hline TAH2-7-12 & 28.2 & 57.57 & 0.16 & 7,509 & 8 & 37 & 3 & -5.8 \\
\hline TAH2-7-13 & 30.0 & 57.31 & 0.15 & 7,537 & 3 & 93 & 3 & -5.8 \\
\hline TAH2-7-14 & 31.8 & 57.31 & 0.15 & 7,592 & 5 & 51 & 3 & -5.4 \\
\hline TAH2-7-15 & 34.2 & 57.80 & 0.16 & 7,452 & 6 & 70 & 3 & -5.9 \\
\hline TAH2-7-16 & 36.1 & 56.38 & 0.16 & 7,491 & 4 & 17 & 1 & -5.6 \\
\hline TAH2-7-17 & 37.8 & 59.19 & 0.17 & 7,657 & 13 & 44 & 4 & -5.8 \\
\hline TAH2-7-18 & 39.8 & 58.26 & 0.14 & 7,655 & 4 & 97 & 7 & -5.9 \\
\hline TAH2-7-19 & 41.4 & 56.67 & 0.15 & 7,432 & 4 & 94 & 3 & -5.7 \\
\hline TAH2-7-20 & 43.8 & 56.61 & 0.15 & 7,390 & 3 & 40 & 2 & -5.2 \\
\hline TAH2-7-21 & 45.6 & 56.90 & 0.15 & 7,449 & 3 & 43 & 3 & \\
\hline TAH2-7-22 & 49.6 & 58.09 & 0.15 & 7,352 & 6 & 21 & 4 & -5.8 \\
\hline TAH2-7-23 & 51.5 & 55.73 & 0.16 & 7,227 & 4 & 117 & 6 & -5.7 \\
\hline TAH2-7-24 & 53.8 & 56.47 & 0.17 & 7,206 & 5 & 69 & 8 & -5.5 \\
\hline
\end{tabular}


Table 4 Appendix continued

\begin{tabular}{|c|c|c|c|c|c|c|c|c|}
\hline Sample id & Vertical distance $(\mathrm{mm})$ & $\mathrm{CaO}(\%)$ & $\mathrm{MgO}(\%)$ & $\mathrm{Sr}(\mathrm{ppm})$ & $\mathrm{Mn}(\mathrm{ppm})$ & $\mathrm{Fe}(\mathrm{ppm})$ & $\mathrm{Cu}(\mathrm{ppm})$ & $\delta^{18} \mathrm{O}(\% \mathrm{VPDB})$ \\
\hline TAH2-7-25 & 55.4 & 56.64 & 0.16 & 7,491 & 7 & 104 & 4 & -5.4 \\
\hline TAH2-7-26 & 57.8 & 55.88 & 0.17 & 7,120 & 3 & 8 & 15 & -6.0 \\
\hline TAH2-7-27 & 60.0 & 59.37 & 0.18 & 7,344 & 3 & 100 & 5 & -5.7 \\
\hline TAH2-7-28 & 61.6 & 58.58 & 0.16 & 7,475 & 10 & 61 & 4 & -5.9 \\
\hline TAH2-7-29 & 64.0 & 56.84 & 0.17 & 7,380 & 10 & 153 & 5 & -6.1 \\
\hline TAH2-7-30 & 65.6 & 56.72 & 0.17 & 7,006 & 3 & 25 & 2 & -6.1 \\
\hline TAH2-7-31 & 68.0 & 55.93 & 0.16 & 7,128 & 3 & 20 & 2 & -5.7 \\
\hline TAH2-7-32 & 69.9 & 58.24 & 0.18 & 7,460 & 3 & 16 & 5 & -5.5 \\
\hline TAH2-7-33 & 72.0 & 57.60 & 0.16 & 7,474 & 9 & 46 & 3 & -5.6 \\
\hline TAH2-7-34 & 74.1 & 55.80 & 0.14 & 7,409 & 4 & 35 & 3 & -5.8 \\
\hline TAH2-7-35 & 76.5 & 56.28 & 0.17 & 7,233 & 4 & 12 & 2 & -5.9 \\
\hline TAH2-7-36 & 78.0 & 55.80 & 0.15 & 7,181 & 5 & 57 & 7 & -5.7 \\
\hline TAH2-7-37 & 80.2 & 57.41 & 0.18 & 6,959 & 3 & 33 & 6 & -5.8 \\
\hline TAH2-7-38 & 82.2 & 57.37 & 0.17 & 7,095 & 3 & 41 & 4 & -6.3 \\
\hline TAH2-7-39 & 84.3 & 58.68 & 0.18 & 7,448 & 4 & 18 & 6 & -5.9 \\
\hline TAH2-7-40 & 86.4 & 57.71 & 0.19 & 6,923 & 3 & 29 & 5 & -6.2 \\
\hline TAH2-7-41 & 88.6 & 58.75 & 0.19 & 7,312 & 9 & 23 & 4 & -5.7 \\
\hline TAH2-7-42 & 90.2 & 56.01 & 0.18 & 6,801 & 2 & 12 & 5 & -5.7 \\
\hline TAH2-7-43 & 92.1 & 57.01 & 0.17 & 6,972 & 3 & 22 & 4 & -6.0 \\
\hline TAH2-7-44 & 94.2 & 58.01 & 0.16 & 7,127 & 3 & 2 & 3 & -6.3 \\
\hline TAH2-7-45 & 95.2 & 61.28 & 0.21 & 7,439 & 4 & 21 & 6 & -6.4 \\
\hline
\end{tabular}

\section{References}

Al-Horani FA, Al-Moghrabi SM, de Beer D (2003) The mechanism of calcification and its relation to photosynthesis and respiration in the scleractinian coral Galaxea fascicularis. Mar Biol (Berl) 142:419-426

Allemand D, Ferrier-Pageè C, Furla $\mathrm{P}$, Houlbrèque F, Puverel S, Reynaud S, Tambutté E, Tambuttè S, Zoccola D (2004) Biomineralisation in reef-building corals: from molecular mechanisms to environmental control. C R Palevol 3:453467

Allison N, Finch AA (2004) High-resolution Sr/Ca records in modern Porites lobata corals: effects of skeletal extension rate and architecture. Geochem Geophys Geosyst 5:Q05001. doi:10. 1029/2004GC000696

Azmy K, Veizer J, Jin J, Copper P (2006) Paleobathymetry of a Silurian shelf: oxygen isotope test. Can J Earth Sci 43:281-293. doi:10.1139/E05-109

Beck JW, Edwards RL, Ito E, Taylor FW, Récy J, Rougerie F, Joannot P, Hénin C (1992) Sea-surface temperature from coral skeletal strontium/calcium ratios. Science 257:644-647. doi: 10.1126/science.257.5070.644

Camoin GF, Montaggioni LF, Braithwaite CJR (2004) Late glacial to post-glacial sea level rise in the Western Indian Ocean. Mar Geol 206:119-146. doi:10.1016/j.margeo.2004.02.003

Chapell J, Polach H (1991) Post-glacial sea level rise from a coral record at Huon Peninsula, Papua New Guinea. Nature 349:147149. doi: $10.1038 / 349147 \mathrm{a} 0$

CISL Research Data Archive (http://dss.ucar.edu/). The National Center for Atmospheric Research and the UCAR Office of Programs, the University Corporation for Atmospheric Research, Boulder
Cohen AL, Hart SR (2004) Deglacial sea surface temperatures of the western tropical Pacific: a new look at old corals. Paleoceanography 19:PA4031. doi:10.1029/2004PA001084

Cohen AL, McConnaughey TA (2003) Geochemical perspectives on coral mineralization. Rev Mineral Geochem 54:15-187. doi: $10.2113 / 0540151$

Cohen AL, Layne GD, Hart SR, Lobel PS (2001) Kinetic control of skeletal $\mathrm{Sr} / \mathrm{Ca}$ in a symbiotic coral: implications for the paleotemperature proxy. Paleoceanography 16:20-26. doi:10.1029/ 1999PA000478

Collins LB, Zhao JX, Freeman H (2006) A high-precision record of mid-late Holocene sea-level events form emergent coral pavements I the Houtman Abrolhos islands, southwest Australia. Quatern Int 145,146:78-85. doi:10.1016/j.quaint.2005.07.006

Corrège $T$ (2006) Sea surface temperature and salinity reconstruction from coral geochemical tracers. Palaeogeogr Palaeoclimatol Palaeoecol 232:408-428. doi:10.1016/j.palaeo.2005.10.014

de Villiers S (1999) Seawater strontium and $\mathrm{Sr} / \mathrm{Ca}$ variability in the Atlantic and Pacific Ocean. Earth Planet Sci Lett 171:623-634. doi:10.1016/S0012-821X(99)00174-0

de Villiers S, Shen GT, Nelson BK (1994) The Sr/Ca-temperature relationship in coralline aragonite: influence of variability in $(\mathrm{Sr} / \mathrm{Ca})_{\text {seawater }}$ and skeletal growth parameters. Geochim Cosmochim Acta 58:197-208. doi:10.1016/0016-7037(94)90457-X

Edinger EN, Browne DR (2000) Continental seas of western Indonesia. In: Shepard C (ed) Seas at the millennium: an environmental evaluation, vol 2. Elsevier, London, pp 381-404

Edinger EN, Jompa J, Limmon GV, Widjatmoko W, Risk MJ (1998) Reef degradation and coral biodiversity in Indonesia: effects of land-based sources of pollution, destructive fishing practices, and changes over time. Mar Pollut Bull 36:617-630. doi:10.1016/ S0025-326X(98)00047-2 
Edinger EN, Limmon GV, Jompa J, Widjatmoko W, Heikoop JM, Risk MJ (2000a) Normal coral growth rates on dying reefs: are coral growth rates good indicators of reef health? Mar Pollut Bull 40:404-425. doi:10.1016/S0025-326X(99)00237-4

Edinger E, Lundberg J, Risk M (2000b) Mid-Holocene fossil reef at Jepara, Central Java, Indonesia: a benchmark of nearshore reef diversity and composition before human disturbance? Ninth International Coral Reef Symposium, Bali, Abstracts p 49

Edinger E, Copper P, Risk MJ, Atmojo W (2002) Oceanography and reefs of recent and paleozoic tropical seas. Facies 47:127-150. doi:10.1007/BF02667710

Edinger EN, Burr GS, Pandolfi JM, Ortiz JC (2007) Age accuracy and resolution of quaternary corals used as proxies for sea level. Earth Planet Sci Lett 253:37-49. doi:10.1016/j.eps1.2006. 10.014

Edinger EN, Azmy K, Diegor W, Siregar PR (2008) Heavy metal contamination from gold mining recorded in Porites lobata skeletons, Buyat-Ratototok district, North Sulawesi, Indonesia. Mar Pollut Bull 56:1553-1569. doi:10.1016/j.marpolbul.2008. 05.028

Emiliani C, Hudson JH, Lidz B, Shin EA, George RY (1978) Oxygen and carbon isotopic growth record in a reef coral from Florida Keys and a deep-sea coral from Blake Plateau. Science 202:627629. doi:10.1126/science.202.4368.627

Epstein S, Buchsbaum R, Lowenstam HA, Urey HC (1953) Revised carbonate water isotopic temperature scale. Bull Geol Soc Am 64:1315-1326

Ferrier-Pagès C, Boisson F, Allemand D, Tambutté E (2002) Kinetics of strontium uptake in the scleractinian coral Stylophora pistillata. Mar Ecol Prog Ser 245:93-100. doi:10.3354/ meps 245093

Fletcher CH (1992) Sea level trends and physical consequences: applications to the US shore. Earth Sci Rev 33:73-109. doi: 10.1016/0012-8252(92)90021-K

Gagan MK, Ayliffe LK, Hopley D, Cali JA, Mortimer GE, Chappell J, McCulloch MT, Head MJ (1998) Temperature and surfaceocean water balance of the mid-Holocene tropical western. Pac Sci 279:1014-1018

Gagan MK, Ayliffe LK, Beck JW, Cole JE, Druffel ERM, Dunbar RB, Schrag DP (2000) New views of tropical paleoclimates from corals. Quatern Sci Rev 19:45-64. doi:10.1016/S0277-3791(99) 00054-2

Gagan MK, Hendy EJ, Haberle SG, Hantoro WS (2004) Postglacial evolution of the Indo-Pacific warm pool and El Ninõ-southern oscillation. Quatern Int 118,119:127-143. doi:10.1016/S10406182(03)00134-4

Hanebuth T, Stattegger K, Grootes PM (2000) Rapid flooding of the Sunda Shelf: a late-glacial sea-level record. Science 288:10331035. doi:10.1126/science.288.5468.1033

Hantoro WS (1997) Quaternary sea level variations in the PacificIndian Ocean gateways: response and impact. Quatern Int 37:7380. doi:10.1016/1040-6182(96)00010-9

Hantoro WS, Pirazolli PA, Jouannie C, Faure H, Hoang CT, Radtke U, Causse C, BorelBest M, Lafont R, Bieda S, Lambeck K (1994) Quaternary uplifted coral reef terraces on Alor Island, East Indonesia. Coral Reefs 13:215-223. doi:10.1007/ BF00303634

Hantoro WS, Faure H, Djuwansah R, Faure-Denard L, Pirazzoli PA (1995) The Sunda and Sahul continental platform: lost land of the last glacial continent in S.E. Asia. Quatern Int 29,30:29-134. doi:10.1016/1040-6182(95)00015-B

Hantoro WS, Nganro N, Shofiyah S, Narulita I, Sofjan J (1997) Recent climate variation signals from corals in Timor, Indonesia. Quatern Int 37:81-87. doi:10.1016/1040-6182(96)00011-0

Hendy EJ, Gagan MK, Alibert C, McCulloch MT, Lough JM, Isdale PJ (2002) Abrupt decrease in tropical Pacific sea surface salinity at the end of Little Ice Age. Science 295:1511-1514. doi: 10.1126/science. 1067693

Hetzinger S, Pfeiffer M, Dullo WC, Keenlyside N, Latif M, Zinke J (2008) Caribbean coral tracks Atlantic Multidecadal oscillation and past hurricane activity. Geology 36(1):11-14. doi:10.1130/ G24321A.1

Holmes KE, Edinger EN, Hariyadi E, Limmon GV, Risk MJ (2000) Bioerosion of live massive corals and branching coral rubble on Indonesian coral reefs. Mar Pollut Bull 40:606-617. doi: 10.1016/S0025-326X(00)00067-9

Horton BP, Gibbard PL, Milne GM, Morley RJ, Purintavaragul C, Stargardt JM (2005) Holocene sea levels and palaeoenvironments, Malay-Thai peninsula, southeast Asia. Holocene 15:1199-1213. doi:10.1191/0959683605hl891rp

Ip YK, Lim LL (1991) Are calcium and strontium transported by the same mechanism in the hermatypic coral Galaxea fascicularis. $\mathrm{J}$ Exp Biol 159:507-513

Lea D, Shen GT, Boyle E (1989) Coralline barium records temporal variability in Equatorial Pacific upwelling. Nature 340:373-376. doi: $10.1038 / 340373 \mathrm{a} 0$

Lescinsky HL, Edinger E, Risk MJ (2002) Mollusc shell encrustation and bioerosion rates in a modern epeiric sea: taphonomy experiments in the Java Sea, Indonesia. Palaios 17:171-191. doi:10.1669/0883-1351(2002)017<;0171:MSEABR >;2.0.CO;2

Longerich HP, Jackson SE, Gunther D (1996) Laser ablation inductively coupled plasma mass spectrometric transient signal data acquisition and analyte concentration calculation. J Anal At Spectrom 11:899-904. doi:10.1039/ja9961100899

Mangerud J (1972) Radiocarbon dating of marine shells, including a discussion of apparent age of recent shells from Norway. Boreas $1: 143-172$

McConnaughey TA $(1989){ }^{13} \mathrm{C}$ and ${ }^{18} \mathrm{O}$ isotopic disequilibrium in biological carbonates. I. Patterns. Geochim Cosmochim Acta 53:151-162

McCulloch MT, Gagan MK, Mortimer GE, Chivas AR, Isdale PJ (1994) A high-resolution $\mathrm{Sr} / \mathrm{Ca}$ and $\delta^{18} \mathrm{O}$ coral record from the Great Barrier Reef, Australia, and the 1982-1983 El Ninõ. Geochim Cosmochim Acta 58:2747-2754. doi:10.1016/00167037(94)90142-2

McGregor HV, Gagan MK (2003) Diagenesis and geochemistry of Porites corals from Papua New Guinea: implications for paleoclimate reconstruction. Geochim Cosmochim Acta 67:21472156. doi:10.1016/S0016-7037(02)01050-5

McIntyre IG (1988) Modern coral reefs of western Atlantic: new geological perspective. Am Assoc Pet Geol Bull 72:1350-1369

Morimoto M, Kayanne H, Abe O, McCulloch MT (2007) Intensified mid-Holocene Asian monsoon recorded in corals from Kikai Island, subtropical northwestern Pacific. Quatern Res 67:204214. doi:10.1016/j.yqres.2006.12.005

Pfeiffer M, Timm O, Dullo WC, Garbe-Schönberg D (2006) Paired coral $\mathrm{Sr} / \mathrm{Ca}$ and $\delta^{18} \mathrm{O}$ records from the Chagos Archipelago: late twentieth century warming affects rainfall variability in the tropical Indian Ocean. Geology 34(12):1069-1072. doi:10.1130/ G23162A.1

Pirazolli PA, Montaggioni LF, Salvat B, Faure G (1988) Late Holocene sea level indicators from twelve atolls in the central and eastern Tuamotus (Pacific Ocean). Coral Reefs 7:57-68. doi: 10.1007/BF00301642

Reimer PJ, Baillie MGL, Bard E, Beck JW, Bertrand CJH, Blackwell PG, Buck CE, Burr GS, Cutler KB, Damon PE, Edwards RL, Fairbanks RG, Freidrich M, Guilderson TP, Hughen KA, Kromer B, Manning GMS, Ramsey CD, Reimer PJ, Reimer RW, Remmele S, Southon JR, Stuiver M, Talama S, Taylor FW, van der Plicht J, Weyhenmeyer CE (2004) IntCal04 terrestrial radiocarbon age calibration, 0-26 cal kyr BP. Radiocarbon 46:1029-1058 
Reynaud S, Ferrier-Pagès C, Boisson F, Allemand D, Fairbanks RG (2004) Effect of light and temperature on calcification and strontium uptake in the scleractinian coral Acropora verweyi. Mar Ecol Prog Ser 279:105-112. doi:10.3354/meps279105

Rollion-Bard C, Blamart D, Cuif JP, Juillet-Leclerc A (2003a) Microanalysis of $\mathrm{C}$ and $\mathrm{O}$ isotopes of azooxanthellate and zooxanthellate corals by ion microprobe. Coral Reefs 22:405415. doi:10.1007/s00338-003-0347-9

Rollion-Bard C, Chaussidon M, France-Lanord C (2003b) pH control on oxygen isotopic composition of symbiotic corals. Earth Planet Sci Lett 215:275-288. doi:10.1016/S0012-821X(03)00391-1

Schneider RC, Smith SV (1982) Skeletal Sr content and density in Porites spp. in relation to environmental factors. Mar Biol (Berl) 66:12-131. doi:10.1007/BF00397185

Scoffin TP, Stoddart DR (1978) The nature and significance of coral microatolls. Philos Trans R Soc Lond B Biol Sci 284:90-122

Stoll HM, Schrag DP (1998) Effects of quaternary sea level cycles on strontium in seawater. Geochim Cosmochim Acta 62:11071118. doi:10.1016/S0016-7037(98)00042-8

Stuiver M, Reimer PJ (1993) Extended ${ }^{14} \mathrm{C}$ database and revised CALIB radiocarbon calibration program. Radiocarbon 35:215230

Sun D, Gagan MK, Cheng H, Scott-Gagan H, Dykoski CA, Edwards $\mathrm{RL}, \mathrm{Su} \mathrm{R}$ (2005) Seasonal and interannual variability of the MidHolocene East Asian monsoon in coral $\delta^{18} \mathrm{O}$ records from the South China Sea. Earth Planet Sci Lett 237:69-84. doi:10.1016/ j.eps1.2005.06.022

Suzuki A, Hibino K, Iwase A, Kawahatai H (2005) Intercolony variability of skeletal oxygen and carbon isotope signatures of cultured Porites corals: temperature-controlled experiments. Geochim Cosmochim Acta 18:4453-4462. doi:10.1016/j.gca. 2005.05.018

Swart PK (1981) The strontium, magnesium and sodium composition of recent scleractinian coral skeletons as standards for palaeoenvironmental analysis. Palaeogeogr Palaeoclimatol Palaeoecol 34:115-136. doi:10.1016/0031-0182(81)90060-2

Swart PK, Grottoli A (2003) Proxy indicators of climate in coral skeletons: a perspective. Coral Reefs 22:313-315. doi:10.1007/ s00338-003-0332-3

Tjia HD (1980) The Sunda Shelf, Southeast Asia. Zeitschrift fur geomorphologie 24:405-427

Tjia HD (1996) Sea-level changes in the tectonically stable MalayThai Peninsula. Quatern Int 31:95-101. doi:10.1016/1040-6182 (95)00025-E

Toscano MA, MacIntyre IG (2003) Corrected western Atlantic sealevel curve for the last 11, 000 years based on calibrated $14 \mathrm{C}$ dates from Acropora palmate framework and intertidal mangrove peats. Coral Reefs 22:257-270. doi:10.1007/s00338-003-0315-4

Veizer J (1983) Chemical diagenesis of carbonates: theory and application of trace element technique. In: Arthur MA, Anderson TF, Kaplan IR, Veizer J, Land, LS (eds) Stable isotopes in sedimentary geology, vol 10. Society of Economic Paleontologists Mineralogists, Short Course Notes, Tulsa, pp III-1-III-100

Veizer J, Ala D, Azmy K, Bruckschen P, Bruhn F, Buhl D, Carden G, Diener A, Ebneth S, Goddris Y, Jasper T, Korte C, Pawellek F, Podlaha O, Strauss H (1999) ${ }^{87} \mathrm{Sr} /{ }^{86} \mathrm{Sr}, \delta^{18} \mathrm{O}$ and $\delta^{13} \mathrm{C}$ evolution of Phanerozoic seawater. Chem Geol 161:59-88

Weber JN, Woodhead PMJ (1972) Temperature dependence of oxygen-18 concentration in reef coral carbonates. J Geophys Res 77:463-473. doi:10.1029/JC077i003p00463

Woodroffe CD, Murray-Wallace CV, Bryant EA, Brooke B, Heijnis H, Price D (1995) Late quaternary sea-level highstands in the Tasman Sea: evidence form Lord Howe Island. Mar Geol 125:61-72. doi:10.1016/0025-3227(95)00028-W

Wyrtki K (1961) Physical oceanography of Southeast Asia waters. NAGA Report No. 2. Scripps Oceanographic Institution, La Jolla, pp 1-195 